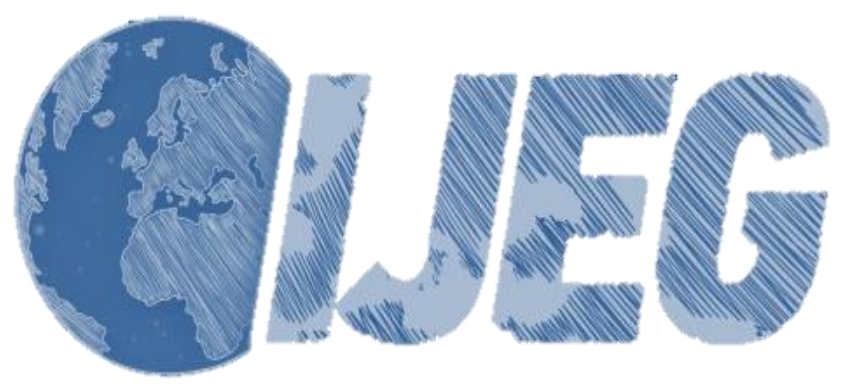

International Journal of Engineering and Geosciences (IJEG),

Vol; 4, Issue; 3, pp. 115-128, October, 2019, ISSN 2548-0960, Turkey,

DOI: $10.26833 /$ ijeg. 535630

\title{
USER-CENTRED DESIGN AND EVALUATION OF MULTIMODAL TOURIST MAPS
}

\author{
Emre Mulazimoglu ${ }^{1 *}$ and Melih Basaraner ${ }^{2}$ \\ ${ }^{1}$ Yildiz Technical University, Graduate School of Science and Engineering, Division of Geomatic \\ Engineering, Remote Sensing and GIS Programme, Istanbul, Turkey \\ (emremulazimoglu7@gmail.com); ORCID ID 0000-0002-9117-1950 \\ ${ }^{2}$ Yildiz Technical University, Department of Geomatic Engineering, \\ Division of Cartography, Istanbul, Turkey \\ (mbasaran@yildiz.edu.tr); ORCID ID 0000-0002-4619-7801
}

*Corresponding Author, Received: 04/03/2019, Accepted: 27/03/2019

\begin{abstract}
User-centred maps are designed to provide users with the geospatial information they need primarily by their interests and thus more powerful support for their geospatial decision-making. In many cases, creating this kind of maps involves designing maps at multiple modes. Tourism is one of the areas that various kinds of maps both analogue and digital are widely used. Well-designed tourist maps can contribute to increasing the attractiveness of a region and the satisfaction of the visitors. Although some applications are available on user-centred multimodal tourist maps for web and mobile environments, there is no comprehensive study dealing with the paper maps. Therefore, this article focuses on the design and production as well as the evaluation of user-centred multimodal tourist maps for the analogue environment in the case of Kyrenia (Girne) district of the Turkish Republic of Northern Cyprus. The study consists of three main phases. In the first phase, a tourist geospatial database was constructed for the district of Kyrenia. In the second phase, user-centred multimodal tourist maps were designed and produced for three types of tourism, considering the prominent characteristics of the district in this respect. In the third phase, user evaluations were carried out for the existing and produced tourist maps. For this purpose, newly designed maps (as a group) and an existing tourist map of the district were evaluated individually and comparatively by potential users of different gender, age and education characteristics by face-to-face survey method. The survey results showed that the user-centred multimodal maps are more preferable than the general tourist map.
\end{abstract}

Keywords: Map Design, Multimodal Tourist Map, User-Centred Design, Kyrenia (Girne) 


\section{INTRODUCTION}

Tourism is the name given to trips to the unknown (Brown, 2007). Tourist maps are the most important documents that help tourists and should be able to answer all questions about the destination that the user visited (Yan et al., 2014). In this respect, well-designed maps have an utmost importance. However, most GIS applications do not consider cartographic design principles sufficiently. This also stems from the poor capabilities of GIS software packages that are often used for making maps. This has started to change along with new cartographic tools incorporated in GIS. People demand highquality maps, and GIS analysts have a responsibility to ensure that they communicate their work effectively using the tools available. Maps may be produced for a general-purpose audience, or to be used by a very specific user group, and so the maps should fit for purpose (Hardy and Field, 2012). In this context, user-centred map design has gained more importance recently. Today, this can be carried out more easily through GIS capabilities (Ulugtekin et al., 2013).

Five basic design principles, well known in cartography, can be mentioned for efficient maps. These principles are shape and ground relationship, hierarchy, contrast, balance and readability. The main reason for the application of these principles is to ensure that the information on the map is delivered to the user effectively (Buckley, 2012).

Nowadays, due to its socio-economic advantages, the interest of the countries in tourism is increasing. So, it is important to make improvements to the existing tourist maps in order to better respond to the growing tourism potential.

\subsection{Related Works}

There are many studies focusing on tourist map design and tourist GIS creation. Clarke (1989) uses a symbol comprehension method to evaluate the efficiency of symbols in the legends of two comparable published tourist maps. Filippakopoulou and Nakos (1995) present one of the first tourist GIS implementations that can allow performing tourismspecific spatial analysis with a map-based interface. Basaraner (1997) and Basaraner and Selcuk (1999) present one of the first examples of tourist GIS applications in Turkey in the case of Antalya city centre based on a large-scale map dataset. Comert and Bostanc1 (1999) present a tourist GIS application based on 1:10000 scale tourist map of Trabzon province (Turkey). Brown et al. (2001) summarize the common errors confronted in tourist web map design and provides suggestions on good design practice. Erdogan and Tiryakioglu (2004) develop a tourist GIS for the province of Afyonkarahisar
(Turkey), aiming to use in tourism promotion activities. Xinwei and Wangfusheng (2005) propose a tourism information system for the city of Beijing (China) through the integration of geospatial information with tourism data. Almer et al. (2006) provide a multi-platform solution for the geographicbased tourism information system. The study covers two-dimensional and three-dimensional visualization of tourism elements with geospatial knowledge and provides an interface to platforms such as Google Earth and Google Maps. Kariotis et al (2007) create a digital, interactive tourist map, which can be transformed according to users' needs. Yin et al. (2008) design a tourism GIS that can be used by tourists who travel independently of any tour program. Then, an online questionnaire was conducted to test the adequacy of the system and the deficiencies of the system were determined according to the results of the survey. Demirci and Kavzoglu (2010) present a tourism GIS application for Kocaeli province (Turkey). Ceylan et al. (2011) present a GIS-based tourist map design for Istanbul historical peninsula (Turkey). Yan and Wang (2012) present a web-based tourist GIS application including virtual reality technology. Alamaki and Dirin (2014) adapt the user-centred tourist map for mobile devices. Pucihar et al. (2014) establish an internet-based user-centred tourism GIS, designed to ensure the sustainability of tourism in the city of Gorenjska (Slovenia). Mutlu et al. (2017) develop a web-based tourist GIS for Bodrum district (Turkey).

\subsection{Motivation and Aim of the Study}

This study focuses on the design and production of user-centred multimodal tourist maps. Tourist maps that are produced for general purposes may be insufficient to meet the information requirements of the specific user groups. Tourism is divided into different sub-types. These sub-types have emerged from some specific needs or preferences of tourists. Therefore, designing user-centred multimodal tourist maps that support different types of tourism in addition to general-purpose tourist maps can provide an additional contribution not only to meeting the specific geospatial information needs of tourists but also the promotion and marketing of tourism potential of a region. Although the design of user-centred maps has been dealt with for web and mobile devices in the literature, making such a design for paper maps, having a wide use, will be a logical approach considering the possible benefits mentioned above. There is no comprehensive study about paper maps within this scope. Therefore, this study aims to create user-centred tourist map designs produced in three different modes (i.e., multimodal) for Kyrenia district of the Turkish Republic of Northern Cyprus (TRNC). These modes correspond to the different tourism types determined by 
considering the tourism characteristics of the district. In addition, these maps (as a group) are evaluated individually and in comparison, to the current tourist map of the district through user surveys.

\section{GENERAL CHARACTERISTICS OF TOURIST MAPS}

Tourist maps are cartographic products designed to provide information on various topics to the tourists visiting an area. These maps play an important role in the promotion of tourism areas (Medynska-Gulij, 2003). Oliveira (2005) mentions the necessity of maps for introducing a city in a touristic sense. With the help of tourist maps:

- User/tourist can access quality information about tourism resources.

- Travel agencies can provide more active guidance for tourists and create alternative routes.

- Managers may obtain a detailed analysis of the geographic distribution of tourism demand and supply in deciding on the regional planning of tourism.

Tourist maps, like other thematic maps, should employ visual hierarchy when they are designed. Applying visual levels in map design allows significant map elements to be emphasized over the others and thus provides effective communication of geospatial information specific to the purpose of the map. Table 1 shows the visual levels for thematic maps (Dent et al., 2009; Wesson, 2018).

Table 1. Basic visual hierarchy of any map, from Visual Level 1 as the highest, most prominent elements, through to Visual Level 5, as the least prominent (adapted from Wesson, 2018).

\begin{tabular}{cl}
\hline $\begin{array}{c}\text { Visual } \\
\text { level }\end{array}$ & Map elements \\
\hline 1 & $\begin{array}{l}\text { Thematic overlay (titles, symbols, } \\
\text { legend, key information) }\end{array}$ \\
2 & $\begin{array}{l}\text { Other (base) map symbols and labels } \\
3\end{array}$ \\
Base map (topography and other features \\
of map body) \\
4 & $\begin{array}{l}\text { Annotation, locator maps, figures } \\
\text { Other useful elements (scalebar, grid, } \\
\text { graticules, frame, tool tips, credits and } \\
\text { acknowledgements) }\end{array}$
\end{tabular}

On a single tourist map, it is often not possible to clearly show all the attractions and resources that a city offers its visitors. In such cases, it may be necessary to produce more than one type of map. In this context, producing tourist maps by considering the prominent tourism types of the region and by putting the user in the centre of the design will increase the interest of the tourist on the map (Yan and Lee, 2014).

\section{USER-CENTRED MAP DESIGN}

The basic philosophy of user-centred design is to put the human factor at the centre of the development process. When designing or developing a product, the designer should focus on what people will use and what to do with it, because a usefully designed product will assist people in decision-making process (Haklay and Nivala, 2010).

It has become easier for people to access geospatial information through developing and changing technological elements, the increasing number of internet-based geospatial data services and free software. However, data and easy access to mapping tools are not a guarantee of an optimized map. The power of the map is related to the ability of the cartographer to convey the information to the user in an accurate way (Shneiderman and Plaisant, 2005).

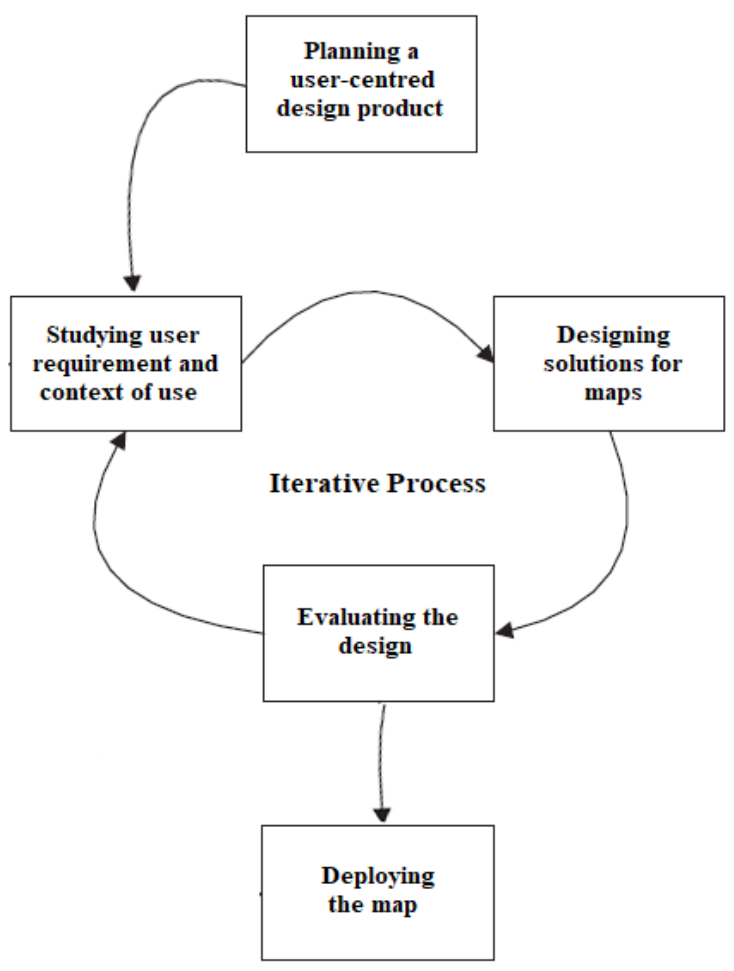

Figure 1. User-centred map design process (adapted from Haklay and Nivala, 2010).

User-centred design can be seen as an iterative process that starts by recognizing the potential user, purpose and tasks. The design process then continues 
to use this information to check the availability of the product. The process continues iteratively until it meets all specified requirements. When the system determines that the user-centred design needs are met, it stops and the result is obtained (Haklay, 2010).

The personalization of tourist maps with user feedback considers user needs in the identification of city symbols, information layers and symbols on the map. In his study, Reichenbacher (2001) argues that minor changes in map symbolization can have a large impact on the user. In addition, Nivala and Sarjakoski (2005) analysed the effects of changes in map characteristics on human and determined that emphasizing colours, increasing contrast and adjusting symbol dimensions for the specific purpose give positive results in user feedback.

\section{METHODOLOGY AND EXPERIMENTAL STUDY}

This study, which deals with the user-centred design and evaluation of multimodal tourist maps, consists of the steps given in Figure 2.

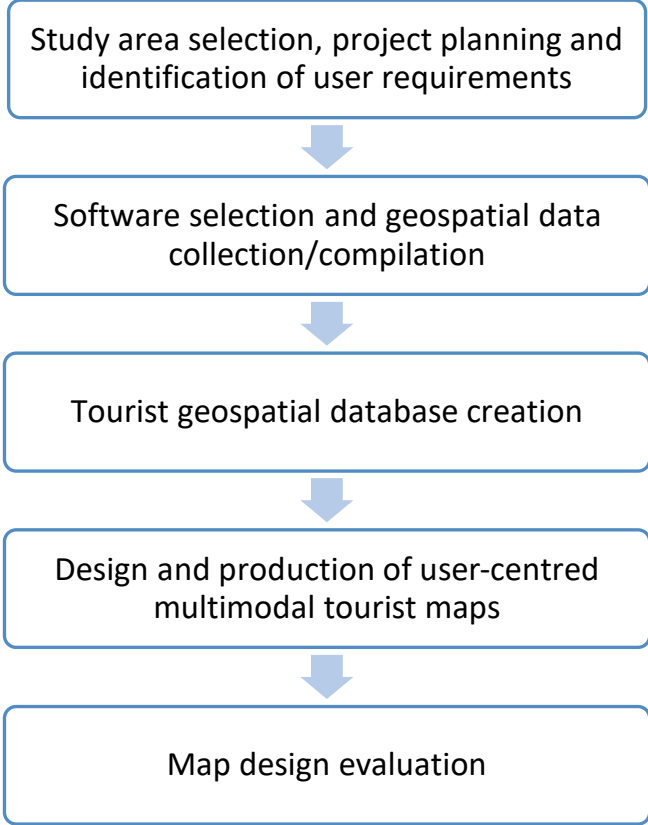

Figure 2. Workflow of the study.

\subsection{Study Area Selection, Project Planning and Identification of User Requirements}

Kyrenia district of the Turkish Republic of Northern Cyprus was chosen as the study area (Figure 3). The geographic location, climate, historical and cultural values and the growing tourism potential have been influential in this decision.
After the study area was selected, it was investigated which tourism types of the district came to the fore and it has been understood that the district offers good opportunities with respect to cultural, gastronomy and entertainment tourisms. Accordingly, it is found appropriate to design different user-centred tourist maps for these types of tourism.

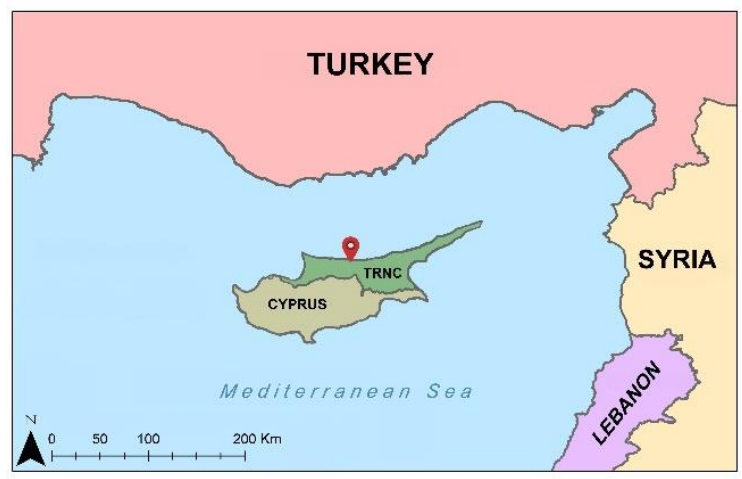

Figure 3. Location of the study area.

Afterwards, the appropriate map scales were decided by taking into account the geographic extent of Kyrenia district as well as the density and distribution of the tourist features in the district. For the maps to be produced, the largest possible scales were selected to be able to present the information that the visitors may need as comprehensive as possible. The distribution of features about historical buildings and cultural heritage in the district was examined and it was decided that 1:3000 scale was suitable for the cultural tourism map. The same scale was found suitable for gastronomy tourism map. For the entertainment tourism map, 1:3 600 scale was found to be appropriate, being different from the other two maps. Since the important entertainment places in the district are in relatively scattered locations, this scale has been selected in to be able to show all of them.

\subsection{Software Selection and Geospatial Data Collection/Compilation}

Three software packages were used in the study. Among them, ArcGIS 10.5 software was used in the creation of a tourist geospatial database and the design of user-centred tourist maps. The models of buildings or structures to be shown in three dimensions were created in SketchUp 2018 software. In addition, Adobe Photoshop CS6 software was used for filtering photographs and designing some point symbols and legends.

OpenStreetMap (OSM) data became the primary data for the creation of the Kyrenia district tourist geospatial database and the design of the usercentred multimodal tourist maps. However, the 
amount of detail of this data was not enough. For this reason, additional data were collected from the field with the hand-held GPS device as well as captured from the satellite image of 2015 by connecting to the Web Coverage Service (WCS) of the DigitalGlobe in the GIS software. Thus, it became possible to remove incorrect data and add missing data. Furthermore, existing paper maps, web maps as well as the websites of Kyrenia Municipality and TRNC Ministry of Culture and Tourism were used as additional data sources. In the cultural tourism map, it was decided to show the significant features of the cultural heritage with photographs. The photographs required for this purpose were obtained through field studies.

Geographic (WGS 84) / EPSG: 4326, being the original coordinate system of OSM data, was used in the study.

\subsection{Tourist Geospatial Database Creation}

The literature (Gerber et al., 1990, Filippakopoulou and Nakos, 1995, Basaraner, 1997, Basaraner and Selcuk, 1999) and various tourist maps were examined to determine the content of the tourist geospatial database on which user-centred multimodal maps rely. For a study wider in scope, a multi-representation spatial database approach may be followed (Memduhoglu and Basaraner, 2018).

Table 2 shows the content of the database. Buildings and structures were represented with points in this database. When they also needed to be shown as polygons in terms of maps, they were externally obtained from the OSM data.

\subsection{Design and Production of User-Centred Multimodal Tourist Maps}

Three user-centred multimodal tourist maps were designed and produced for three types of tourism (cultural tourism, gastronomy tourism and entertainment tourism) in this phase. Thanks to the multimodal maps, tourists visiting the district will be able to use the appropriate tourist map according to their interests. Thus, tourists will be able to reach more specific geospatial information for their purpose(s) of the visit and make their decisions easily and quickly.

This phase includes generalization and symbolization operations applied to the geospatial data.

\subsubsection{Generalization}

In this phase, some generalization operations were performed on the base map (i.e. OSM data) in order to remove unnecessary detail, prevent the graphic conflicts and ensure an aesthetic appearance in the maps. Various generalization operations were applied interactively and thus the appearance of the features was modified. Since the contents of the maps were partly different, the generalization differed slightly depending on the map type.

The general steps of the generalization were as follows:

- Buildings were selected/eliminated depending on their necessity for target map.

- Buildings (area) were collapsed to point.

- Buildings with detailed geometry were simplified.

- Parking lots, recreation areas and cemetery were simplified and smoothed.

- Most of the roads were enlarged.

- In most cases, texts and in some cases, point symbols were displaced slightly when required.

\subsubsection{Symbolization}

In this phase, convenient symbols were determined for each feature to be shown on the map. For this purpose, many local and foreign tourist city maps, as well as common web maps such as Google Maps, Yandex Maps and Bing Maps were examined. In the first stage, the symbols used in the library of GIS software were used. In cases where this is not sufficient, the symbols taken from the existing digital maps were used after being rearranged in the image editing and graphic design software and added in the map through the GIS software.

For the maps, light and pastel colours were preferred for the background features such as blocks and recreation areas (Figure 4), and more vivid colours were used for the significant features. The roads in the tourist geospatial database are represented with line geometry as in the OSM data. However, at large scale maps, roads are represented as areas (polygons). So, areal road representation (i.e. areal symbols) were obtained with buffering in the GIS software. Three different symbol widths were determined for three different types of roads within the geographic extent of the study area (Table 3 ). Since the roads are significant for tourist maps, their symbol sizes (i.e., width) were usually set larger than the corresponding road widths in reality. Afterwards, the roads were appropriately coloured by considering their hierarchy. Border lines were also added to the road symbols for emphasizing their representation. 
Table 2. The content of the tourist geospatial database.

\begin{tabular}{|c|c|c|c|}
\hline CATEGORY & FEATURE CLASS & GEOMETRY & ATTRIBUTES \\
\hline Accommodation & $\begin{array}{l}\text { Hotel } \\
\text { Hostel } \\
\text { Holiday Village } \\
\text { Pension } \\
\text { Guesthouse }\end{array}$ & Point & $\begin{array}{l}\text { Feature_name, } \\
\text { Feature_subclass, } \\
\text { Number_of_stars, } \\
\text { Address }\end{array}$ \\
\hline Transportation & $\begin{array}{l}\text { Road } \\
\text { Airport } \\
\text { Port } \\
\text { Bus Station } \\
\text { Taxi Stops } \\
\text { Parking Lot }\end{array}$ & $\begin{array}{l}\text { Line } \\
\text { Point } \\
\text { Point } \\
\text { Point } \\
\text { Point } \\
\text { Point }\end{array}$ & $\begin{array}{l}\text { Feature_name, } \\
\text { Feature_subclass }\end{array}$ \\
\hline Cultural Heritage & $\begin{array}{l}\text { Historical Building } \\
\text { Museum } \\
\text { Monument } \\
\text { Ancient Harbour } \\
\text { Ancient Lighthouse } \\
\text { Library } \\
\text { School } \\
\text { Cemetery }\end{array}$ & Point & $\begin{array}{l}\text { Feature_name, } \\
\text { Purpose_of_use, } \\
\text { Definition }\end{array}$ \\
\hline Entertainment & $\begin{array}{l}\text { Bar } \\
\text { Disco } \\
\text { Theatre } \\
\text { Cinema } \\
\text { Scuba Diving } \\
\text { Paragliding } \\
\text { Shore Fishing } \\
\text { Casino }\end{array}$ & Point & Feature_name \\
\hline Service & $\begin{array}{l}\text { Bank } \\
\text { Exchange Office } \\
\text { ATM } \\
\text { Post Office } \\
\text { Prayer Room } \\
\text { Information Office } \\
\text { Public Toilet } \\
\text { Court } \\
\text { Gas Station } \\
\text { Car Rental }\end{array}$ & Point & Feature_name \\
\hline Emergency & $\begin{array}{l}\text { Police Station } \\
\text { Fire Department } \\
\text { Hospital } \\
\text { Cottage Hospital } \\
\text { Pharmacy }\end{array}$ & Point & Feature_name \\
\hline Recreation & $\begin{array}{l}\text { Green Area } \\
\text { Park } \\
\text { Playground } \\
\text { Sports Field }\end{array}$ & Polygon & Feature_name \\
\hline Facility & $\begin{array}{l}\text { Restaurant } \\
\text { Cafe } \\
\text { Market } \\
\text { Shopping Centre }\end{array}$ & Point & $\begin{array}{l}\text { Feature_name, } \\
\text { Feature_subclass }\end{array}$ \\
\hline
\end{tabular}




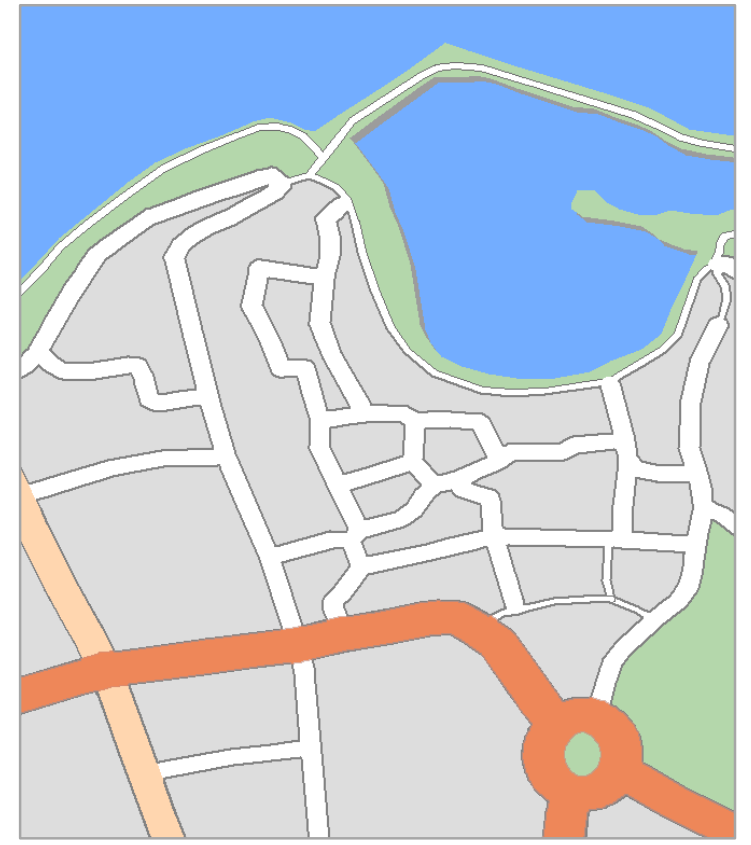

Figure 4. Colour selection for the base map.

Table 3. Properties of roads shown on the map.

\begin{tabular}{lccc}
\hline Colour & $\begin{array}{c}\text { Colour } \\
\text { Code }\end{array}$ & $\begin{array}{c}\text { Feature } \\
\text { Subclass }\end{array}$ & $\begin{array}{c}\text { Road Symbol } \\
\text { Width (m)* }\end{array}$ \\
\hline & $\begin{array}{c}\text { R:255 } \\
\text { G:255 }\end{array}$ & Street & 10 \\
B:255 & & \\
\hline & R:255 & \\
G:214 & Avenue & 17 \\
B:175 & & \\
\hline & R:238 & Main & 20 \\
G:135 & Avenue & \\
B:89 & &
\end{tabular}

Kyrenia Castle, being the most salient landmark in the district, was shown with a 3D symbol (Figure 5). To this end, its 3D model was created in the 3D modelling software. Today, 3D models of cultural heritage collected with photogrammetric techniques are more accessible (Yakar and Dogan, 2018).

The modelling process was carried out in four stages. In the first stage, the footprint of Kyrenia Castle, digitized from satellite imagery, was extruded to its real dimensions. In addition, an enlargement process was applied to the Shipwreck Museum building within the castle so as to make it more distinguishable on the map. After this process, the photographic texture of the castle was applied to its wall. In the third phase, some landscape features around the castle (i.e., tree, bench, lighting lamp) were added in the model. In the last stage, the model was rendered by applying a suitable daylight setting.

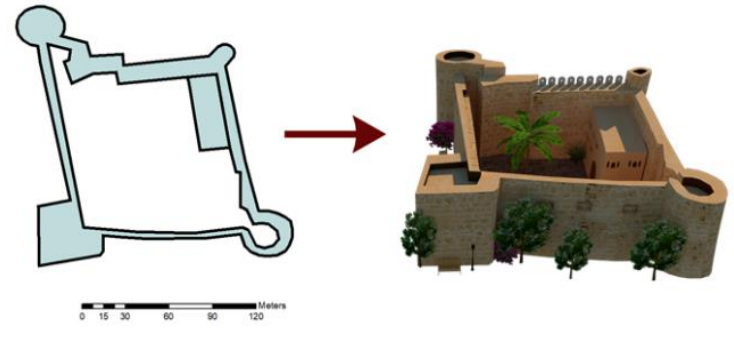

Figure 5. Digitized footprint (left) and 3D model (right) of Kyrenia Castle.

In the multimodal maps, those features were shown as common but sometimes with different symbology (Figure 6): Tourism Information Offices, Museums, Historical buildings and structures, Monuments, Harbour, Lighthouses, Theatres, Library, Schools, Playgrounds, Accommodation facilities, Banks, ATMs, Hospitals, Pharmacies, Parking lots, Bus stations, Taxi stops, Airport service stops, Gas stations, Roads, Administrative buildings, Post offices, Courts, Fire departments.

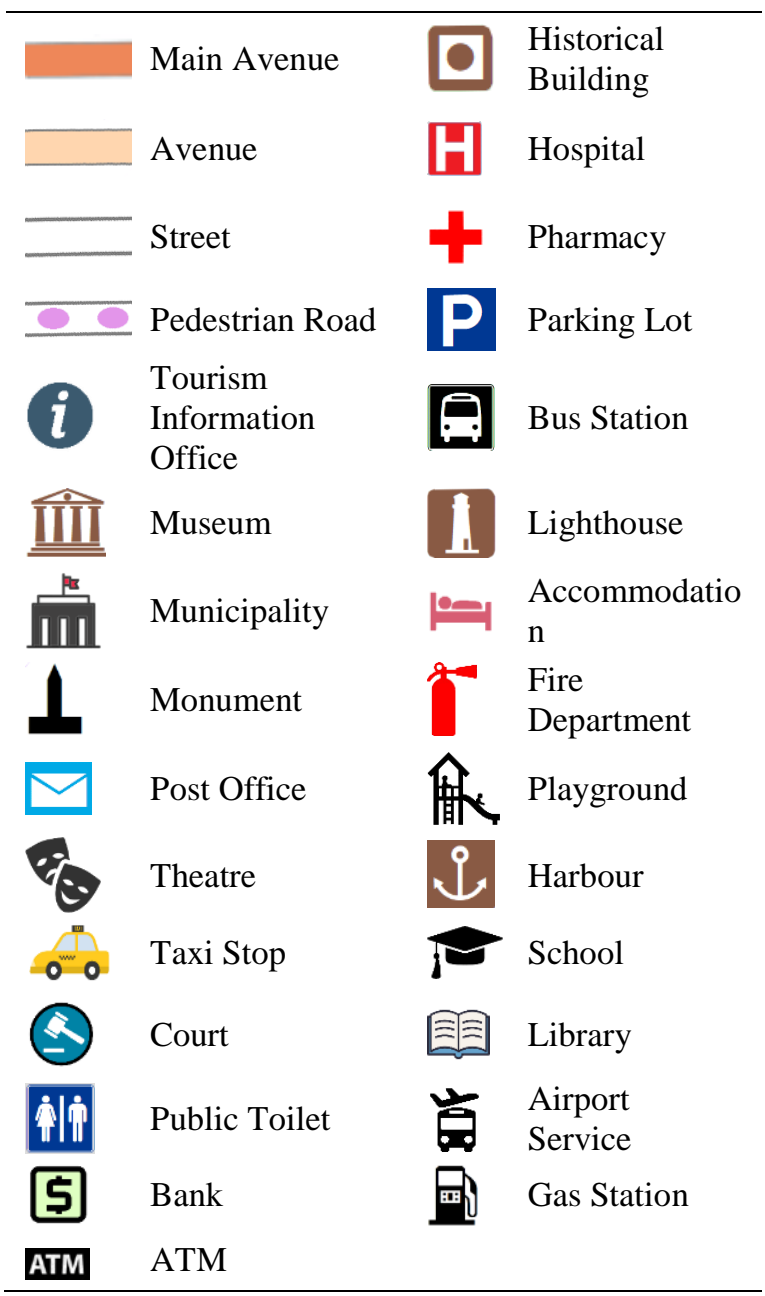

Figure 6. Common map symbols used for all of the maps. 
In the cultural tourism map, for historical and cultural landmark features, photographs are used to represent them more saliently after applying visual filters (e.g., dynamic lighting, watercolour effect, etc.) (Figure 7).

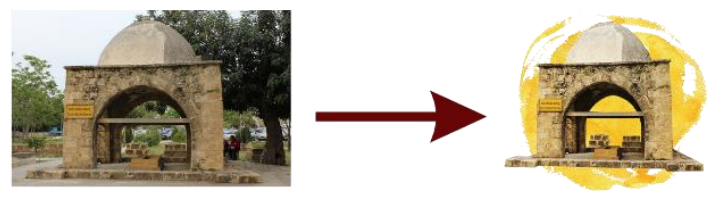

Figure 7. Photograph of a landmark after visual filtering.

In the gastronomy tourism map, the restaurants and other gastronomy related features were shown using appropriate point symbols (Figure 8). All symbols in this map were designed in the image editing and graphic design software.

Seafood Restaurant

Figure 8. Map symbols specifically used for different restaurant types and other gastronomy related features.

In the entertainment tourism map, those features were shown, unlike other tourist maps (Figure 9):
Boat tour offices, Extreme sports centres, Football fields, Casinos, Bars/Discotheques (Bars were shown also in the gastronomy tourism map), Rent a yacht services, Car rental companies.

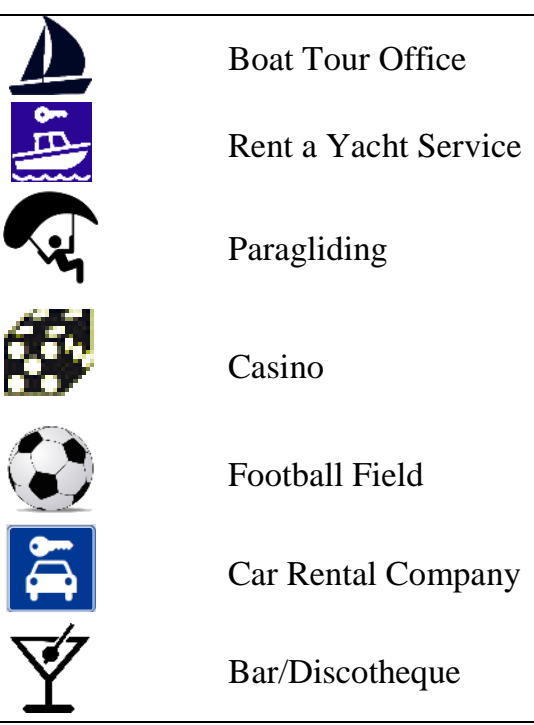

Figure 9. Map symbols specifically used in the entertainment tourism map.

\subsubsection{Other elements}

In this phase, some other elements were added to the map designs. Those were as follows:

- Title

- $\quad$ Scale bar (both linear and ratio scale).

- Grid references

- Index

- Inset map

- North arrow

\subsection{Map Design Evaluation}

A survey was conducted to test to evaluate the design and the usability of user-centred multimodal tourist maps against the general tourist map of the district. The number of participants in the survey was 60. The survey questions were prepared in two different languages (Turkish/English) considering domestic and foreign tourists. The data were collected by face-to-face survey method with the support of a local tourism agency. The questionnaires were completed under the supervision of the first author. 


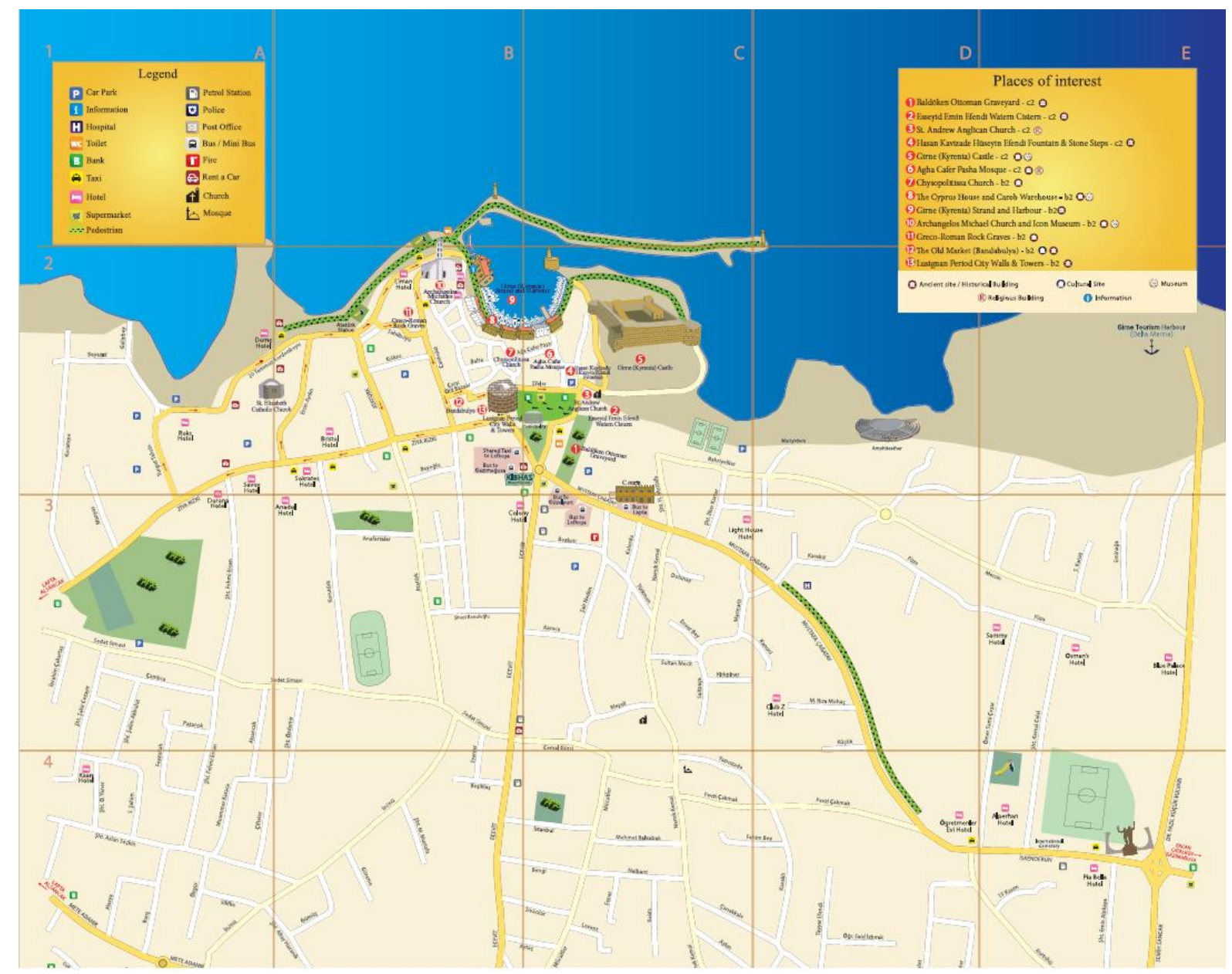

Figure 10. General tourist map of Kyrenia (not to scale) (URL 1).

The survey consists of four main parts. In the first part, individuals were asked about some types of personal information such as age, gender and educational status, as well as what kind of media (digital or paper) they used during their tourism activities. In the second part, nine questions were asked to evaluate the general tourist map of Kyrenia (Figure 10), produced by TRNC Tourism and Promotion Office, and the user-centred multimodal tourist maps (as a group), produced in this study. The participants were expected to score 1 to 5 in these questions. These scores mean: 1: very bad, 2: bad, 3 : enough, 4: good, 5: very good. In the third part of the survey, six questions were asked to compare usercentred multimodal tourist maps with the general tourist map of Kyrenia. In the last part of the survey, the questionnaire was completed by asking which of the maps (general purpose or user-centred multimodal) they prefer to use during their visits when all the factors were considered.

\section{RESULTS AND DISCUSSION}

Three user-centred multimodal tourist maps of Kyrenia were designed and produced by considering the specific information needs of different visitors, as mentioned above. Figures 11, 12 and 13 show these maps created for cultural tourism, gastronomy tourism and entertainment tourism, respectively. The maps are shown smaller than the actual size and scale in these figures. 

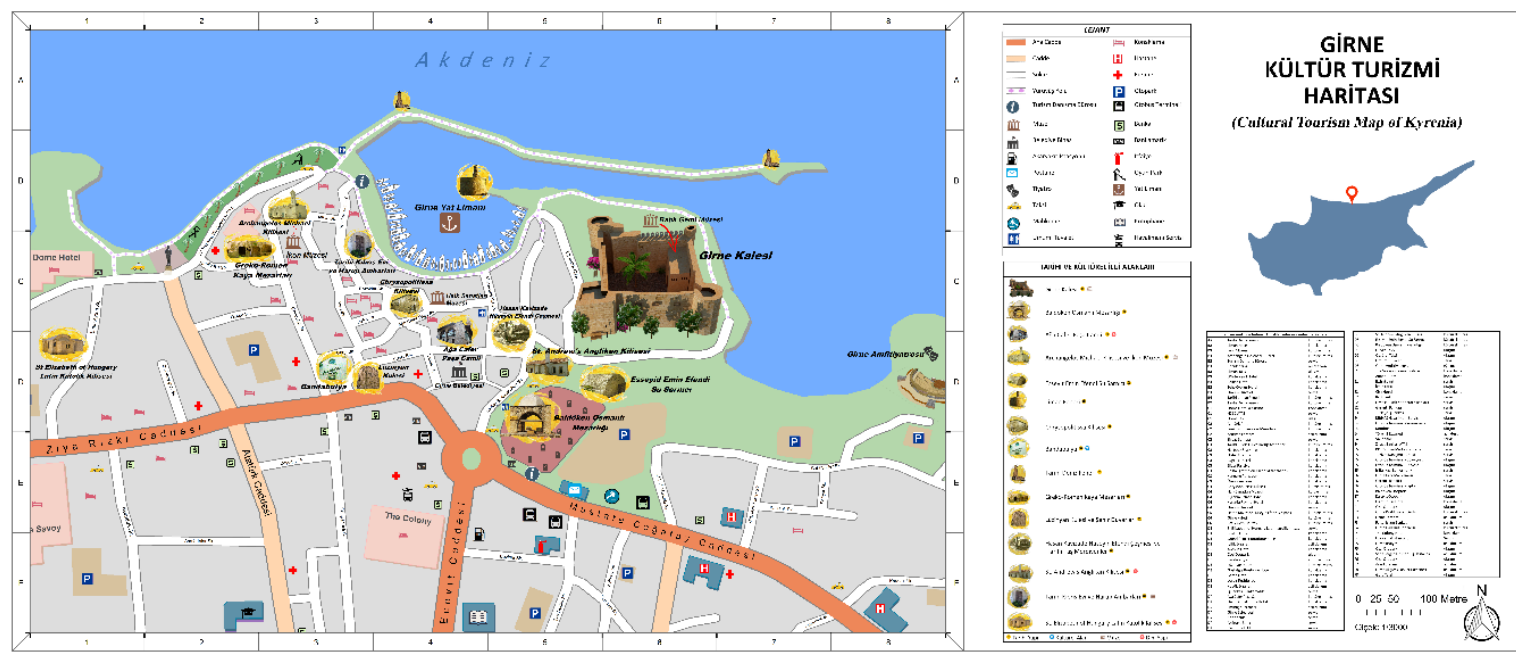

Figure 11. Cultural tourism map of Kyrenia (not to scale).
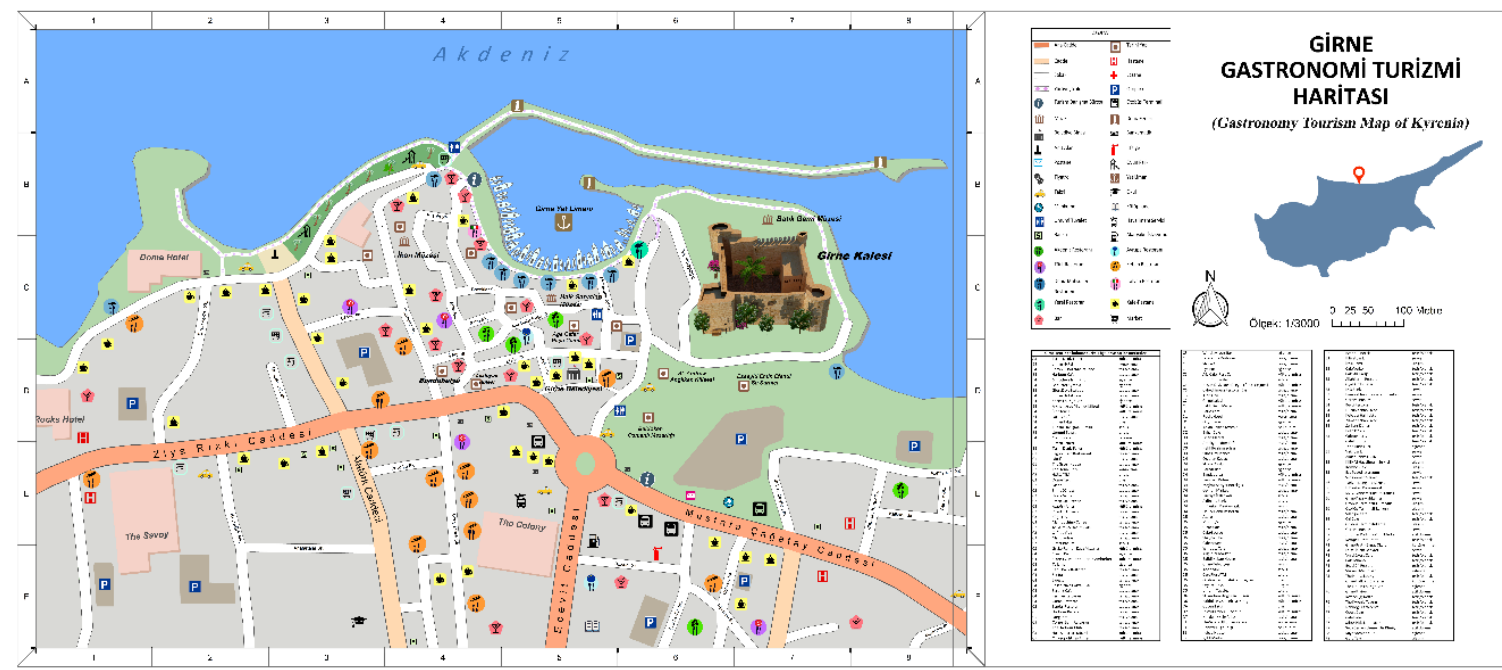

Figure 12. Gastronomy tourism map of Kyrenia (not to scale).

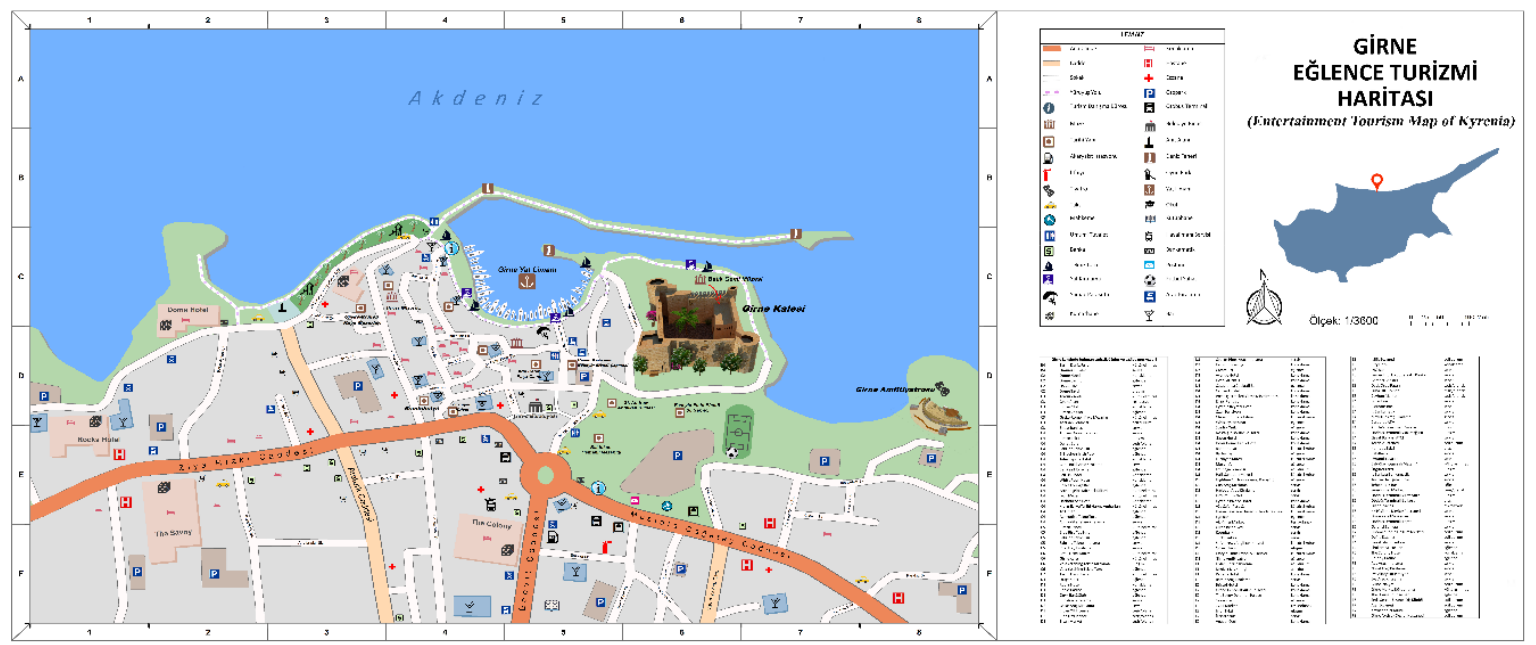

Figure 13. Entertainment tourism map of Kyrenia (not to scale). 
The evaluation of maps was performed by user surveys. The profile of the participants in terms of gender, age and educational status was given in Table 4.

Table 4. Demographic profile of the survey participants $(\mathrm{N}: 60)$.

\begin{tabular}{lll}
\hline Variable & Category & \% \\
\hline Gender & Female & 46.7 \\
& Male & 53.3 \\
\hline Age & $18-35$ & 28.3 \\
& $36-55$ & 36.7 \\
& 56 or above & 35 \\
\hline Educational & Primary/Secondary & 6.7 \\
Status & School & \\
& High School & 30 \\
& University & 63.3 \\
\hline
\end{tabular}

The survey findings show that paper maps are still used commonly (Figure 14). The majority of the participants said that they use paper and digital maps together during their visits.

The findings show that the general tourist map of Kyrenia is insufficient in some aspects. The usercentred multimodal tourist maps were found more preferable and useful. The average score (out of 5) for the variables of the maps given by participants is shown in Table 5.

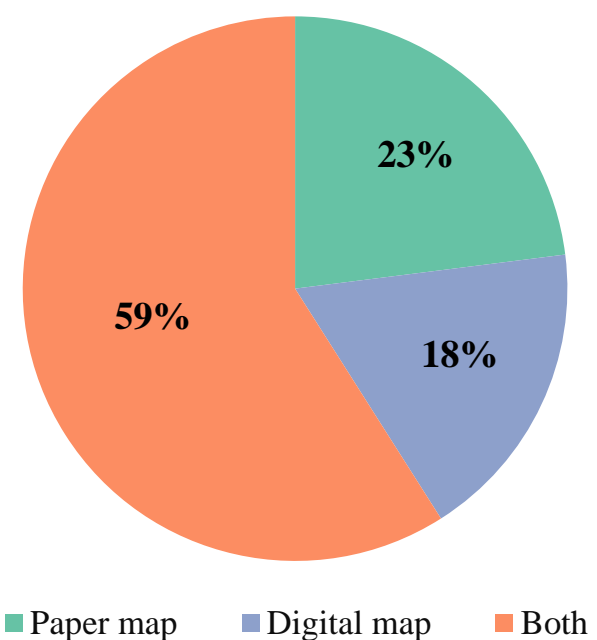

Figure 14. Map type preference of the participants.

Another remarkable result of the survey was in the field of map aesthetics and visual quality. In this respect, the average score of the general tourist map of Kyrenia was 2.15 out of 5 . The user-centred multimodal maps got 4.32 out of 5 . This shows that they are more attractive in view of the visitors.

Table 5. Average scores of the variables of maps.

\begin{tabular}{lcc}
\hline \multicolumn{1}{c}{ Variable } & \multicolumn{2}{c}{ Average Score } \\
& General Tourist Map & $\begin{array}{c}\text { User-Centred Multimodal } \\
\text { Tourist Maps }\end{array}$ \\
\hline Scale (level of detail) & 3.50 & 4.12 \\
\hline Map size & 4.08 & 3.92 \\
\hline Aesthetic quality & 2.15 & 4.32 \\
\hline Map legend & 3.32 & 4.35 \\
\hline Easiness for reading and understanding & 2.77 & 4.00 \\
\hline Scope of information provided & 2.58 & 4.07 \\
\hline $\begin{array}{l}\text { Placement (Existence) of landmarks for } \\
\text { wayfinding }\end{array}$ & 3.17 & 4.23 \\
\hline $\begin{array}{l}\text { Sufficiently comprehensive information for } \\
\text { touristic places }\end{array}$ & 2.77 & 4.13 \\
\hline Covering all street names of interest & 3.62 & 4.25 \\
\hline
\end{tabular}


Table 6. The map preference made by the participants according to some technical specifications.

Variable

\begin{tabular}{lcc} 
& $\begin{array}{c}\text { General Tourist Map } \\
\text { \% }\end{array}$ & $\begin{array}{c}\text { User-Centred Multimodal } \\
\text { Tourist Maps } \\
\text { \% }\end{array}$ \\
\hline Map size and scale & 38.33 & 61.67 \\
\hline $\begin{array}{l}\text { Ability to respond to specific user } \\
\text { requirements }\end{array}$ & 3.33 & 96.67 \\
\hline Ease of use & 35 & 65 \\
\hline $\begin{array}{l}\text { Map language (legibility and clarity) } \\
\text { Map aesthetics/visual quality } \\
\text { colours, symbols, legends etc.) }\end{array}$ & 30 & 70 \\
\hline $\begin{array}{l}\text { Ease of wayfinding (accurate and } \\
\text { complete representation of landmarks } \\
\text { and points of interest) }\end{array}$ & 8.33 & 91.67 \\
\hline
\end{tabular}

Another investigation was made on how the demographic profile of the participants affected their map preferences. Accordingly, as the education level of the participants increases, the interest to the general tourist map decreases, and the interest to the user-centred multimodal tourist maps increases (Figure 15). In terms of age and gender, no significant difference was observed in the preferences.

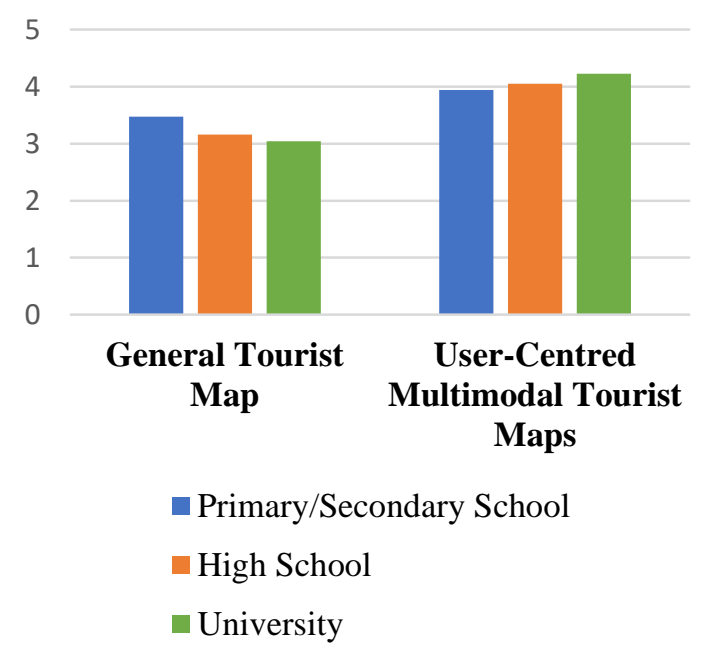

Figure 15. The score averages given by the participants to the tourist maps according to the educational status.

\section{CONCLUSIONS}

Tourist maps are cartographic products that provide geospatial information for tourists visiting a place. These maps are important for the visitors to percept and explore a region that they visited or planned to visit. Therefore, tourist maps not only affect the satisfaction of the tourists during the visit but also may impact their decision for destination choice.

This study presented the design and production as well as the evaluation of user-centred multimodal tourist maps, which communicate more specific information to the tourists in comparison to general tourist maps. In this context, the map designs for the Kyrenia district of TRNC were developed for three particular types of tourism (cultural, gastronomy and entertainment), based on the tourist geospatial database constructed in the earlier phase of the study. According to the map evaluation study based on user surveys, it was observed that user-centred multimodal tourist maps created in this study were more preferred by the participants. Besides, it is observed that it is important to show the information on the tourist maps correctly, specifically and attractively as much as possible.

Future works may focus on other kinds of tourism maps. In addition, a web map interface allowing user interaction and supporting multiple map modes may be developed for this purpose. Furthermore, user studies may be done with a larger number of participants. 


\section{REFERENCES}

Alamaki, A. and Dirin, A. (2014). Designing mobile guide service for small tourism companies using user centered design principle, International Conference on Computer Science, Computer Engineering, and Social Media, 12-14 December 2014, Thessaloniki, Greece.

Almer, A., Schnabel, T., Stezl, H., Stieg, J. and Luley, P. (2006). A tourism information system for rural areas based on a multi-platform concept. In: J.D. Carswell and T. Tezuka (eds.) Web and Wireless Geographical Information Systems Proceedings of the 6th International Symposium (W2GIS'06), LNCS vol. 4295, 31-41.

Basaraner, M. (1997). Turistik Amaçlı Coğrafi Bilgi Sistemi Oluşturulması, Master of Science Thesis, YTU, Istanbul, Turkey.

Basaraner, M. and Selcuk, M. (1999). From tourist map to tourist GIS, Third Turkish-German Joint Geodetic Days, 23-26 September 1999, Istanbul, Turkey.

Brown, A., Emmer, N. and Worm, J. (2001). Cartographic design and production in the internet era: the example of tourist web maps. The Cartographic Journal 38(1), 61-72.

Brown, B. (2007). Working the problems of tourism. Annals of Tourism Research 34(2), 364-383.

Buckley, A. (2012). Make maps people want to look at: five primary design principles for cartography. ArcUser Winter 2012, 46-51.

Cartwright, W., Peterson, M.P. and Gartner, G. (2007). Multimedia Cartography, Second Edition. ISBN: 978-3-540-36650-8., Springer, Heidelberg.

Ceylan, M., Sarici, H. and Basaraner, M. (2011). İstanbul tarihi yarımada için coğrafi bilgi sistemi tabanlı turistik harita tasarımı, TMMOB Coğrafi Bilgi Sistemleri Kongresi 31 Ekim-4 Kasım 2011, Antalya, Turkey.

Clarke, L.M. (1989). An experimental investigation of the communicative efficiency of point symbols on tourist maps. The Cartographic Journal 26(2), 105110.

Comert, C. and Bostanci, T. (1999). Turist bilgi sistemleri ve Trabzon örneği, Yerel Yönetimlerde Kent Bilgi Sistemi Uygulamaları Sempozyumu, 1315 Ekim 1999, Trabzon, Turkey.

Demirci, Y.Z. and Kavzoglu T. (2010). Kocaeli turizm bilgi sisteminin tasarlanması, III. Uzaktan Algılama ve Coğrafi Bilgi Sistemleri Sempozyumu, 11-13 October 2010, Kocaeli, Turkey.
Dent, B., Torguson, J. and Hodler, T. (2009). Cartography: Thematic Map Design, Sixth Edition. ISBN: 978-0-072-94382-5, McGraw-Hill, Boston.

Erdogan, S. and Tiryakioglu, I. (2004). Turizmtanıtım faaliyetlerinde coğrafi bilgi sistemlerinin kullanımı: Afyon örneği, 3rd GIS Days in Turkey, 69 October 2004, Istanbul, Turkey.

Filippakopoulou, V. and Nakos, B. (1995). Is GIS technology the present solution for creating tourist maps?. Cartographica: The International Journal for Geographic Information and Geovisualization 32(1), 51-62.

Gerber, R., Burden, P. and Stanton, G. (1990). Development of public information symbols for tourism and recreational mapping. The Cartographic Journal 27(2), 92-103.

Haklay, M. and Nivala, A. (2010). User-centred design. In: M. Haklay (ed.) Interacting with Geospatial Technologies, ISBN: 978-0-470-998243, Wiley, Sussex.

Hardy, P., and Field, K. (2012). Portrayal and cartography. In: W. Kresse and D.M. Danko (eds.) Springer Handbook of Geographic Information, ISBN: 978-3-540-72680-7, Springer, Heidelberg.

Kariotis, G., Panagiotopoulos, E., Karitou, G. and Karanikolas, N. (2007). Creation of a digital interactive tourist map with the contribution of GPS and GIS technology to visualization of the information, XXIII International Cartographic Conference, 4-10 August 2007, Russia.

Medynska-Gulij, B. (2003). The effect of cartographic content on tourist map users. Cartography 32(2), 49-54.

Memduhoglu, A. and Basaraner, M. (2018). Possible contributions of spatial semantic methods and technologies to multi-representation spatial database paradigm. International Journal of Engineering and Geosciences 3(3), 108-118.

Mutlu, A., Vural G., Aydin, O., Guney, B., Hamamci S. F., Aya, A., Sur, N., Ulugtekin, N. and Bektas Balcik, F. (2017). Bodrum turistik bilgi sistemi web ve mobil uygulamaları, 16. Türkiye Harita Bilimsel ve Teknik Kurultay1, 3-6 May 2017, Ankara, Turkey.

Nivala, A.M. and Sarjakoski, L.T. (2005). Adapting map symbols for mobile users, 22th International Cartographic Conference Mapping Approaches into a Changing World, 9-16 July 2005, A Coruna, Spain.

Oliveira, I.J. (2005). Cartografia aplicada ao planejamento do turismo. Boletim Goiano de Geografia 25(1), 29-46. 
Pucihar, A., Malesic, A., Lenart, G. and Borstnar, M.K. (2014). User-centered design of a web-based platform for the sustainable development of tourism services in a living lab context. In: B. Auilani, T. Abbate and A.M. Braccini (eds.) Smart Organizations and Smart Artifacts, Springer, Cham.

Reichenbacher, T. (2001). Adaptive concepts for a mobile cartography. Journal of Geographical Sciences, 11(1), 43-53.

Sneiderman, B. and Plaisant, C. (2005). Designing the User Interface: Strategies for Effective HumanComputer Interaction, Fourth Edition. ISBN: 0-32119786-0, Pearson, Boston.

Ulugtekin, N.N., Dogru, A.O. and Bildirici, I.O. (2013). CBS haritalarının tasarımı, TMMOB Coğrafi Bilgi Sistemleri Kongresi, 11-13 November 2013, Ankara, Turkey.

Wesson, C. (2018). Layout, balance, and visual hierarchy in map design. In: A.J. Kent and P. Vujakovic (eds.) The Routledge Handbook of Mapping and Cartography, Routledge, Abingdon, Oxon.

Xinwei, Z. and Wangfusheng, W. (2005). The design and development of Beijing tourism information system based on GIS. Geomatics \& Spatial Information Technology 28(4),33-35.

Yakar, M. and Dogan, Y. (2018). GIS and threedimensional modeling for cultural heritages. International Journal of Engineering and Geosciences 3(2), 50-55.

Yan, L. and Lee, Y. (2014). Are tourists satisfied with the map at hand?. Current Issues in Tourism 18(1), 1048-1058.

Yan, X. and Wang, Y. (2012). Development of Zaozhuang tourism information system based on WebGIS. International Journal of Computer Science Issues 9(6), 249-252.

Yin, P., Jiang, X. and Ma, Y. (2008). Research on tourism information systems for self-drive tourists, IEEE International Conference on Service Operations, Logistics and Informatics, 2, 1915-1921.

URL 1, KKTC Turizm Tanitma ve Pazarlama Dairesi, http://turizmtanitma.gov.ct.tr/TanıtımBroşürleri/Bölgeler/Girne, accessed on 1 March 2019. 